\title{
教養としての高分子 2
}

\author{
網状高分子とその歴点的役割
}

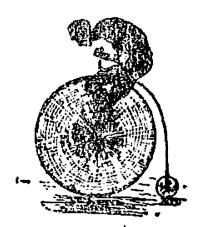

ドクトル・ Noahnytk

発見が需要をよび起こす。改良によったいっそうのびた需要に供給が追いつかなくなると， それを補抢うとするいろいろの妢力が，また新たな発見を導く。はじめは見すごされていた欠 点が, 明らかに認識されたとき, あるいは他の新しい産業の分野で新たな特性の要求が起こっ たとき，いきいきとした発展の波が広がる。そして科学者が，その裏にひめられた原理を解き 明し，次の進歩への灯をかかげるのを待つ。第 2 回は,こうした壮大な物語のごく一部である。

\section{2-1. 天然ゴムの歴史}

セルロース，とくにニトロセルロースを起点とした一 つの道は, いろいろの曲折を経た後に, 1937 年遂にナ イロンにまで到達した。しかし今日の高分子をささえる 力の源には, この他にもら一つの出発点があった。見す ごすことのできぬとの起点は天然ゴムである。

スペインの探険家 Christopher Columbus (1456〜 1506)は多くの発見をなし遂げているが, 1493 年, Haiti 島に到達したとき，彼の一行は現住民の子供が，木の樹 液からつくったふしぎな，重い，黒い球を投げて遊んで いるのをみて驚いた。これがョーロッパ人がゴムを見た

「教養としての高分子」学1月号から連载しはじめた。 専門の細分化によって生じるいるいるな支障が各方面で指摘さて

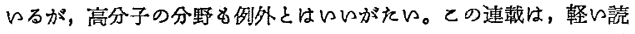
み物を通じて，中ゃ広い視野にた口て高分子学見直す機会を，会員 諸賢に提供するとともに，より若い人々を高分子の㑯域に誘い入れ るととをめざしている。

「物語」はしばしぱ，他人による証明を，自力による理解と混同さ せる危険をむっている。委員会む「数养」とはこのように安直なむ のであるとは决して考えていない。むしろ読み流されれ後で, その

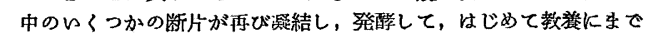
高まるのであって，そのプロセスは読者で自身の心にゆ艺ねてい る。

一貫したムードを保つれめに、、ささか執筆上に工夫はしたが， 内容の主点は物性に括かれて沏り，教養委員会での合作である。む り迈むべき内容につレては読者諸士から委員会あてにいるいるとア

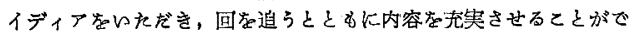

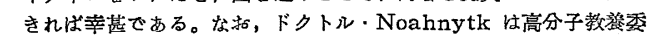
員会の委員全員のイニシャルを合成してつくっれ名称である。( 1 月 号の序交より)

第 1 回の「敛状高分子の暨史と高分子概念の成立」は Vol. 17 No. 190, (1 月号) 67 ページ。
最初である。その球は「まるで生き物のように，はねは ずんだ」と書き伝觉られている。

現住民たらは，ヨーロッパ人の見なれないこの物質を 遊びのためばかりでなく，他にもいろいるに用いてい た。たと党ば、ツボの形をした泥のかたまりをつくり，

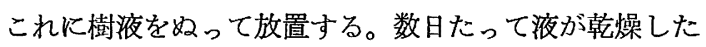
ころ,これをたたいて中をくだき，粉にしてはかき出し， 粉にしてはかき出してゆき中を空にする。こうしてでき たものは泥をゴムで固めた，水のもらないツボになって いた。現在われわれの用いているゴム製品にも，多くの 場合，充テン剂と称する相当多量の粉体が入れてある が，南アメリカの現住民たちは，Columbus の来る前の 大昔から似たよらなものをつくっていたのである。

しかし，この上うな天然ゴムは，ほんの少量しかョー ロッパに持ち込まれなかった。といらのは，天然のま まのゴムは，樹液の形で運涪うとすれば，直ちに沈殿し て变質してくるし，また固まったゴムも，当時の大西洋 航路を長期間かかって渡る間汇，すっかり劣化してベタ ベタしたものになってしまったからである。

長い年月の間に，たくさん種類のあるゴムの木のらち から，良質な樹液を出す品種も見定められたし，また樹 液から，もちのよい形でゴム塊をつくる方法も徐々に進 歩してきた。ようやく 1770 年になって, あるイギリス 人が，ゴム塊でこする（rub）ことにより，紙に鉛筆で 書いた字を消すことができることを見出し，そのことを 彼の著書の中に書いた。それまで現住民が用いていた木 (cao) の淚 (ochu) に従って caoutchouc といわれてい 
た天然ゴムは，これ以来 rubber という英語風の呼び名 を得た。このイギリス人は Joseph Priestley (1733〜 1804) であるが, 彼の化学に括ける業蹟には, 酸素の発 見といら輝かしいものがあるため, rubber の名付け親 であるといら栄誉の方は忘れられがちである。

\section{2-2. 天然ゴムの工業と栽培}

1819 年ごるになると，ロンドンでは靴下どめや胴着 に入れるために，うすいゴムの板を細長く切って,ゴム ひもをつくる工場ができている。この工場は 1926 年に は Charles Macintosh(1766 1843) と, Thomas Hancock (1786 1865) の 2 人の共同経営のものとなるが, この 2 人はともに天然ゴムの歴史の上に不減の名を残し ている。前者は, 彼らの工場の製品を通じて，一般名詞 にまでなった。つまり，ゴムびきの防水布は，今でも英 語では Mackintosh (ドイッ語では Mackintosch) と 呼ばれている。他の一人，Hancock の方はすぐ炏の物 語りにつながる。

彼らによって，天然ゴムは工業製品として，上飞述べ たような形で市民生活の中に入り込みはじめはしたるの の，寒い月には固くなってヒビわれてくるし，逆に䁔い 日が続くと柔らかくなり，ベトベトしてきてしまって， 今日われわれの身近かのゴムから想像されるものとは打 よそ縁遠い劣悪な品質のものであった。アメリカの南 北戦争（1860～1865）のころをとり扱った小説「風と共 に去りぬ」を読むと，主人公の Scarlet O'hara が身仕 度をする折，布製に鯨骨の入ったコルセットで，ウェス トを召使いに 17 インチをでしめさせる場面がある。女 性が着心地のよい(のであろう) ゴム入りのコルセット を愛用できるようになるには，当時の天然ゴムよりる， もっともっと改善された品質のものが，一般に普及され る日まで待たねばならなかったことを物語っている。

このような問題は，逆にい党ば化学者にとってきわめ て甪力ある研究題目を提供していることである。そして, ここにもまた鍊金術の手法がみられる。たゆみのない, あれこれの試みの末, 1832 年にドイッの F. Ludersdorff と，ほぼ時を同じくしてアメリカの N. Hayward とが、ゴムが劣化し、ネバネバになってしまうのをイオ ウが防ぐ効果をもつことを見出した。そして 1839 年の 1月アアメリカ人 Charles Goodyear (1800〜1860) は ゴムにイオウと顔料の鉛白（塩基性炭酸鉛）を混ぜをも のを台所のストーブの上で煮てみて，ゴムが顕著に硬く なることを発見した。こうして処理したゴムの一片は， 1842 年の暮汅は前に述べたロンドンのゴム工場の経営 者 Hancock の手に入る。 Hancock はこの方法を改良 して生ゴムを溶けたイオウにつけて処理する方法を開始 て，圭れとともにゴムの「加硫 (Vulcanization)」とい

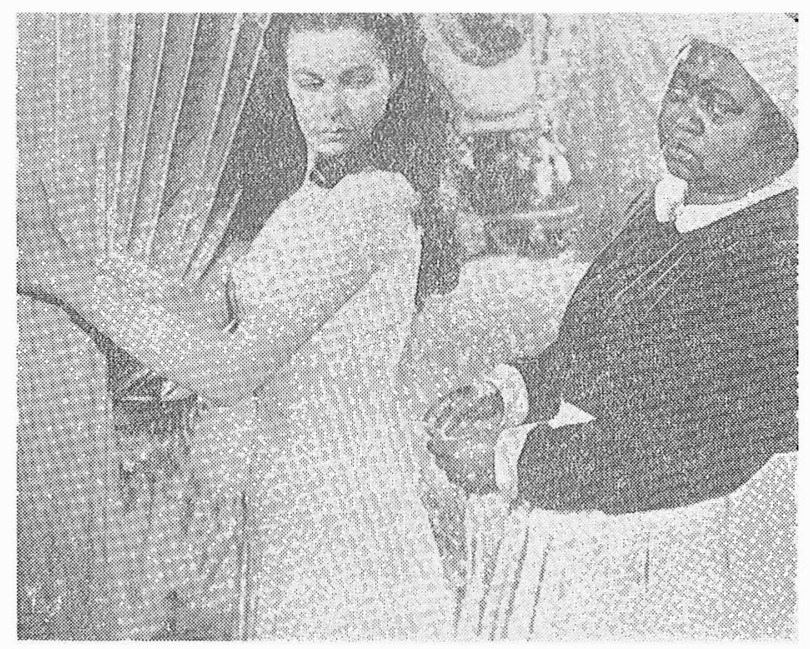

MGM 映画「風と共に去りぬ」より，(MGM 社提供)

う言葉をはじめてつくった。イオウと化学作用を起こさ せることによって、ゴムは今日わ的れが見るように， 温度によってあまり影響されない安定な特性を持った, きわめて弾性に富んだ物質としての地位を確立する。こ うして典型的な網状高分子は人類のものとなったが,こ れがどんな構造のものであるかが明らかにされるまでに は 100 年に近い年月を要する。Hancock のこの発明は, 1843 年のイギリス特許となり，一方 Goodyear の発明 は 1844 年にアメリカの特許となった。今から，120年 以上子昔，もうすでに，わずか一かけらの新物質が大西 洋をこ党て人の手から手にと渡り，その結果，きわめて 類似の特許が時を同じくして出現する例がここにみられ る。発明, 発見のッバぜり合いは，別に近ごろ始まった ことではないようだ。

こらして加硫ゴムが世現われたちょらどそのころ， ペダルつきの自転車が発明され，それまで乘り手が足で 直接に地面をけって走らせる原型から，現代の子供の三 輪車を思わせる型に恋わってきた。そして鋼鉄技術が進 歩してすぐれた中空鋼管ができるようになった 1870 年 代には，軽いフレームをもち，ペダルの力を鎖で後輪に 伝える型のものとなる。1 889 年スコットランドの獣医 John Boyd Dunlop (1840～1921)はこれに空気入りタイ ヤをとりつけ，自転車はまことにスマートなのりものと なった。一方では, 荷馬車用のがんじょらなタイヤとし ても,ゴムはますますその需要を拡大してゆくのである。

こうなってくると，南米の原始林の中で, 手あたり次 第に樹液をとるだけでは，ゴムの生産が追いつかなくな る。その上，過大に樹液をしぼりとられたゴムの木は死 隇に頻して，ますをすゴムの価格の高騰ををねいた。

ここで再び Hancock が登場する。彼は工業化学者と してすぐれていただけでなく，きわめて広い視野を持っ。 た人だったのだろう。ゴムの将来を見通した Hancock は,ゴムの栽培を始めるように熱心に説いて回わった。 彼の意見を入礼た英国政府印度局の役人は，ゴムの独占 を計ってゴムの種子や苗木の他領への持出しを禁じて 


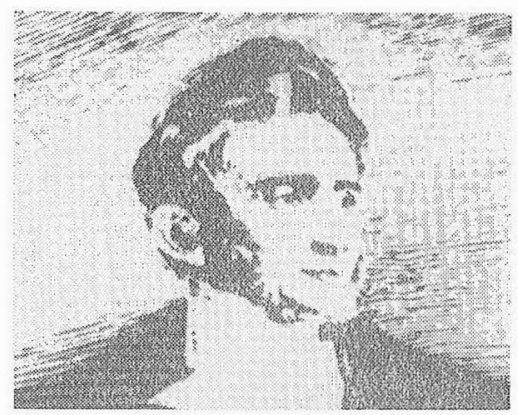

Chales Goodyear ("The British Rubber Industry”より, 天然ゴム研究所提但)

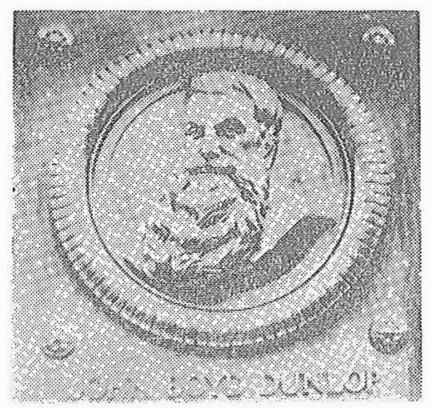

John Boyd Dunlop ("The British Rubber Industry”ょり, 天然ゴム研 究所提(供)

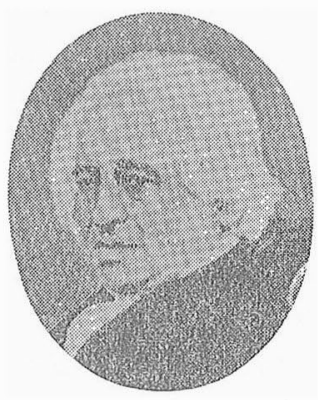

Thomas Fancock ("Fistry of the Rubbeer Industry" より，天然ゴム砳究所提(供)
いたブラジルの目をくぐって，英領の植民地への移植を くわだてた。多くの苦労の末, ゴムの木の種子はなずイ ギリスの植物園の温室に，そしてそこで苗木としたもの が，さらに東南アジアの植民地にと移植されて行く。こ の過程で，それまで良質のゴムを産出する木として知ら れていた 2 種の中，ブラジルの現住民がエヴィアと呼え でいたもの (hevea braziliencis) だけがシンガポール 化移され他の一つ, castilloa elastica移植汇成功しな かった。このようにして 1877 年に, たった 22 本の苗 木がマレー半島の一角に根づいた。栽培をはじめる原動 カとなった Hancock が死んでから 12 年もたった後の

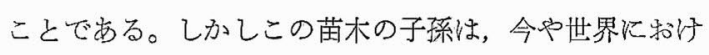
る天然ゴムの生産量のほぼ゙ $3 / 4$ 亿当る量をつくり出すた 至っている。

\section{2*3. 初期のゴムの物理学}

人間がバネの力を最初に利用したのは，怙そらく弓で あろう。武器としての弓は, 西欧でも, 支那でも，日本 でも，穴の他のあらゆる所で用いられ，弓を使ったこと のない民族を探すことの方が困䧼である。だが，このタ イプ以外のバネの力となると, 文明の中にはなかなか現 われてこない。金属の板バネやより洗錬されたコイル スプリングが登場するのは, 容易に想像されるようにヤ 金技術が発達して，良質の素材と，それを十分に活用す る加工技術が確立されたずっと後世のことである。

これ対してゴムは，手でたやすく数倍にも引き伸ば すことがでさ，手をはなすとたち孪りるとの長さに戻る といらきわめて特徴のある性質を示した。

天然ゴムがようやく一般のものになると同時浪，極端 K大きな変形を加えても，直ちに原形を回復するゴムの 性質が，物理学者の興味をひくようになったのは，しご 々当然である。1806 年に John Gough はゴムについて のいくつかの実駼結果を発表した。その中沫＼cjkendゴムを 急沪き伸ばすと熱が出ること、特もりをかけて引き伸
ばしてあるゴムひもを暖めると縮んでくること，冷たい 水の中でゴムを引き伸ばすと，引き伸ばされたままでも とに戻らないが，これらを温水の中に移してやると弾性 をとり戻して長さがもとに戻ること，などゴムの弾性的 性質と熱的性質を関係づける重要な点がすべて含まれて いた。

このころ, 化学界では L. A. Lavoisier (1743 1794) が，燃焼の理諭を完成して、フロジストン説を打破して はいたが，彼の元素表にはまだ熱素（calolic）が光素と ともに記載されていて，雨者とも科量できない流動体で 西ると考党られていた時代なので, Gough はこれらの 現象をすべて熟素の作用として説明しょうとしている。 熱力学といら学問が形づくられて行ったのは,ちょうど この時期である。気体の体積と温度の関係と詳しく調べ てBoyle-Charle の法則を見出した J. A. Charle (1746 〜1823), 熱とエネルギーの同一性をみごとな実験で 1840 年K証明した James Prescott Joule (1818 1889), その Joule の話を 1846 年に聞いて深い感銘を 受け, すぐ次の 1847 年には絶対温度という概念に到達 した William Thomson (後の Lord Kelvin, 1824 1907）らがはなやかに活躍していた絶対温度といら考兵 が確立されたしばらく後 J.E. Clausius (1822〜1888) によって, エントロピーの概念が 1865 年に確立される が,この年はちょらぞ第 1 回の話の説き起こしに用いた 年にもあたる。

発展の途上にある熱力学の理論を用いて，Kelvin は 1857 年火金属のバネは温度が上ると伸びやすくなる事 実から，急激に金属バネを引き伸ばすと，温度が下るこ とを予言したが，そのついでに，ゴムたついても言及し て，扣もりをつけたゴムのひもは，温度を上げるときっ

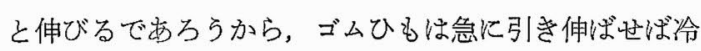
たくなるはずだと述べている。このとき，Kelvin はそ れより 50 年添ど前に行なわれた Gough の実験に気つう いていなかったので，まちがった推論から出発したこと 
になる。しかて，Joule の残した記録の中ほは，この後 Kelvin はすぐ Gough の観察に気づき, 自分の熱力学 的理論で，前提とした推論が Gough の観察で㧍りに訂 正されるならば直ちに正しい結論が理論的に得られるこ とに満足したとのことである。

測定器具がまだあまり精密につくられなかった時期に 和いては、ゴム悢気体と並んで, 可逆的な大きな変形を させることができる意味で，物理学者にとっては手ごる な研究対象であった。すぐれた実験家の Joule は Thomson の理論を確かめるために, 1859 年に天然ゴムの精 密な実験を行なっている。これは，圧縮した気体を急に 膨張させると温度が下る, という, 有名な Joule-Thomson の実験（1961 年）の行なわれるよりも 2 年前であ り, 当時の物理学者の心の中に天然ゴムがいかに大きな 地位を占めていたかをよく示すものであるう。Joule の ゴムについての実験は，Gough の得た結果と，三つの らち，二つをでは，完全に合致した。しかし第 3 の結 論,つまり冷水の中でゴムを引き伸ばすと, Gough の観 察では, もとの形戻らなかったが, Joule の実験では 冷水の中でもひもゴムは直ちにもとの長さに戻った。こ のらがいは, 実は Goodyear らによる加硫の発見が，ち ょらどこの両者の実験の閒に行なわれたことが原因であ る。そのため, Joule が加硫ゴムで奉験したのに対し， Gough は生ゴムの性質を䙾察していたのである。しか し，彼らはこれを分子棈造に関係ら゙けて理解することは できなかった。これについてのより精しい話は, 別の場 所でもら一度行ならこととしょう。

\section{2-4. エボナイトとベークライト}

ゴムとイオウを反応させる実験が行なわれると間るな く,もっともっと多量に, ゴムの中に数十\%までイオウ を入れてみることも試みられた。雨者を混ぜて，長時間 熱した結果は，黒いかたい塊となった。それを適当な温 度に熱して, 強い力で変形させると, ある程度いろいる

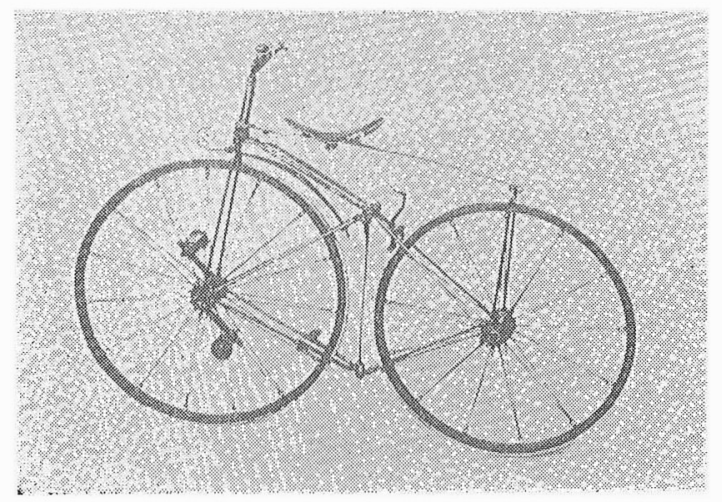

1889 年でろ英人レイノルドとメイズが共同考案したもので車輸に 初めてむくのゴムタイヤが使用されれ。当時の人は, 化物自転車 と呼んだといわれている。((財) 自転車産業振興協会提供)
な形炕することもできたが，むしろ削り出して磨くと美 しいッヤを示すことに特徵があった。その色合いからこ の物質は，マレーや東インド特産する貴重な木材の黒 タン (ebony) になぞらえて, ebonite と名づけられ た。人工の材料が天然品に相似た名前をもら劣るように なったのは, ebonite が最初ではなかららか。

だがエボナイトは，木とは非常に異なる利点をももっ ていた。電気に対するすぐれた絶縁性であるエボナイト がいりのころから一般化したものかは明らかでない。し か乙，このころ，先駆的な仕事を次々となし遂げて電磁 気学の基礎を礎いた Michael Faraday (1791〜1867)の 実験ノートには，エボナイトを種々に用いた実験器具の スケッチがたくさん現われている。

電気の絶縁物としては, 1909 年にベークライトが出 現するが，この誕生もまたきわめて示唆と教訓偪むも， ののように思われる。フェノール類の化学反応について は，いろいろの知識がもらつみ上げられてはいたが，そ の中で，何とかして，新しい物質をつくり出そうという 試み努力をつづける化学者の 1 人は,フェノールとホ ルムアルデヒドを反応させてみた。できたものはみご とに樹脂状であった。試験管にこびりついたこのやっか い物け，トコトンどの溶媒にも溶けず，ひどくかたかっ た。彼はこれを“染料の時代”の化学者のように捨ても よかったが，時代はすでにセルロイドやエボナイトを知 っていた。

しかし，この化学者, Leo Hendrick Bakeland は, それ以上にわれわれの学びとるべき多くの特色のある 考光方をしている。第 1 に, 彼はフェノールとホルマリ ソの反応物の示す樹脂状物の性質を，なんとか利用して やろう，ということを考党たのである。こうした基本的 な態度でよく調べてみると，反応の初期には油状であっ， たものが，熱し続けてゆくと初めて本当にかたくなるも のであることがわかった。さらに反応の途中で，ちょう， ぞ, 油状からかたくなり始めたころを見計って冷してや

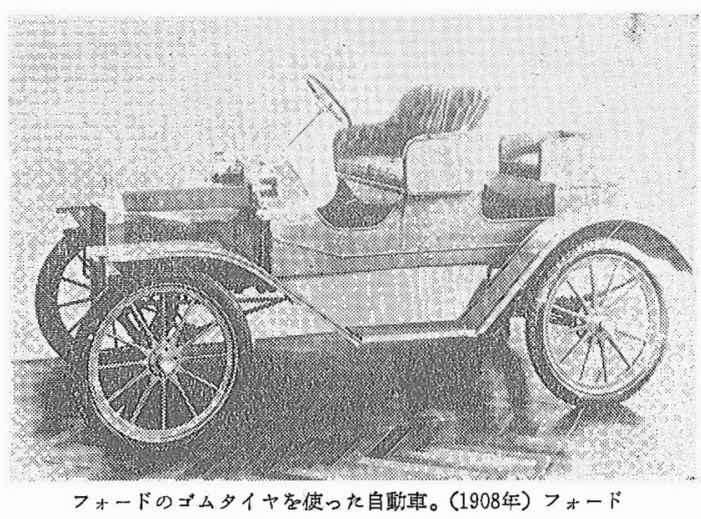

自動車㙛物館庍藏(こニーエンペイヤモータ一提供) 
Leo Hendrick Bakeland (住友ベークライト提供)

ると，冷光て塊状となるが，これを再び温度を上げて熱 してやると，やはり最終的には同じようにかたくなると いう「中休み」をさせられるものであることもわかった。 そして，こういら「中休み」のときに粉研して，木粉 や，綿くずと混合して適当な型に入れ，その後再び熱し て硬化させると，容易にいろいろな型に成形でさること も見出した。しかも，こうして一度成形してしまうと， もら決して変型しない強固なものになるのである。 Bakeland の発明が米国特許として現われてくるのは 1909 年である。

しかし彼がその前年 1908 年（明治 41 年）飞日本に 2 件む特許申請をしている事実は, ベルギー生れの彼の 国際的感覚からみた日本の地位を反胦するものとして興 朱ぶかい。

彼のとった考兄の，学ぶべき第の 2 点は, こうしてで きる人材料一彼は自分の名にちなんで Bakelite と名付けた一一を，眅売する方法をる工夫したことであ る。彼は反応の中間物や，それを木粉などといるいるに 混合した各種の銘柄を用意するとともに，それを型に入 れて熱して硬化させるための Bakelizer と呼ぶ機械を つくり，成形のやり方を指導しながら，成形材料と成形 機械の両方を成形技術つき販売したのである。彼によ り，成形業者という新しい職種が育成された。

木粉などの入っていないベークライトは，色といい，
つやといい，松やにのような樹脂にそっくりだった。そ のため人びとはこれを合成樹脂とす呼んだ。そ後，合 成樹脂は多種多様の豊富さをもってくるが，今でも死々 んど大部分の合成樹脂は,材料としての樹脂メーカーと， その加工業者とに分かれて最終留品にまでつながって行 く。そしてべークライトに至っては，その流通過程は全 く Bakeland のきり開いた形のまをといってもよかる 亏。

Bakeland の，この上うな商品の流通機蔌をで考完ぬ いたやり方に加えて, 新しい時代の要請にもらょうど合 致したこの樹脂は, 急速な発展の道をたどる。というの は, T. A. Edison (1847 1931) が発電機をつくり, 電 灯会社の経営に着手したのがこのころであり, 手ごろな 電気絶緑物が大量に要求されはじめるときだったのであ る。もちろんエボナイトもあった。陶磁器やガラスもあ った。しかし，簡単に，すみやかに，いろいろな形のむ のをつくりらる点でベークライトはこれらに比べてきわ だってすぐれた性質をむっていたのである。そして，適 当な絶縁体を求めて苦心を続けていた電気産業もスイッ チ,ソケットなど家庭内に進入するための部品をつくる に適したベークライトを得て、より容易に発展の道を歩 みらるよらになったのである。

ゴムとベークライトは一度固めてしまうと，もう単に 暖めただけでは成形でさない点で，前に述べたセルロイ ドとは異なりここに鎖状高分子と網状高分子との大き な差の一つが示されている。この点では，前の時代のや っかいものの樹脂状物は網状高分子の系誁のものであっ た。

この上うに歴史をふりかえってみると，いつも時代は 新物質を得て発展し，その発展途上でさらに新しいもの が要求されて進んできていることがわかる。現在のわれ われも，その延長線の上にあるといえよう。

\section{「高分子化学」「高分子」,「海外高分子研究」の合本用ファイルができました}

かねてょりご希望のありました合本用ファイル（写真 参照）を作成いたしました。購入希望者は下記あてお申 込み下さい。

\section{東京都中央区銀座東 5-2-4 本州ビル 4 階} 高子学会会員課合本用ファイル係 電話 東京 (03) (543) 3771 (代表)

な拉，「高分子」用は 1 個炕半力年分(約 6 冊)，「高分子 化学」「海外高分子研究」用は 1 個に 1 力年分 (12冊) が

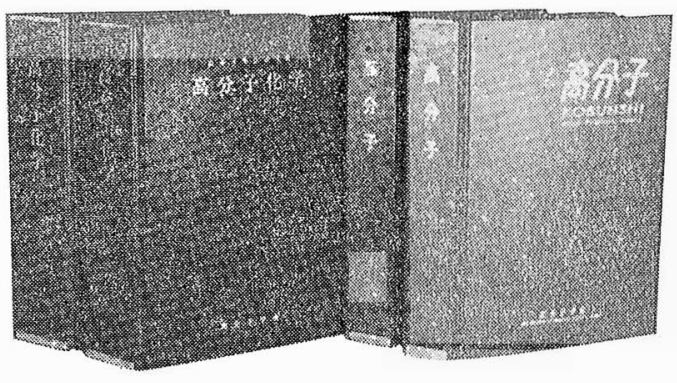
ビられるようになっています。1 個 150冈（送料実費） 